\title{
ANALISIS KOMPARASI KINERJA KEUANGAN BPR MILIK SWASTA DAN BPR MILIK PEMERINTAH DAERAH DI PROVINSI JAWA TENGAH PERIODE 2014-2016
}

\begin{abstract}
Abstrac
This study aims to analyze the Differences in Performance of Private Owned Rural Banks and Local Government-Owned Rural Banks in Central Java Province by using financial performance ratios namely Non Performing Loans (NPL), Capital Adequacy Ratio (CAR), Loan to Deposit Ratio (LDR). ), Earning Assets Quality (KAP), Operating Income Operating Expenses (BOPO) and Return on Assets (ROA). The method used to analyze the data is the Different Test using the Independent T test. This study used the SPSS Version 19. Analysis tool. The population used in this study was BPR in Central Java. The sample of this study is the Rural Bank owned by the Central Java Regional Government and the Private Rural Banks in Central Java Province. Sample selection using purposive sampling. Based on the Independent Test of the T test, there are differences in the NPL and KAP ratios between the Regional Government-owned BPR and the Private BPR, while there are no differences in the CAR, LDR, BOPO and ROA ratios.
\end{abstract}

Kata Kunci : Kinerja Keuangan, Bank Perkreditan Rakyat, Independent T test

\section{PENDAHULUAN}

Sebagai wujud dari hasil yang telah dicapai perusahaan dalam periode waktu usaha, tidak terlepas dari kinerja yang dilakukan pihak perusahaan. Jika kinerja perusahaan baik, akan menghasilkan prestasi yang baik pula, begitu juga sebaliknya. Kinerja keuangan suatu perusahaan sangat bermanfaat bagi berbagai pihak (stakeholder) seperti investor, kreditur, analisis, konsultan keuangan, pialang, pemerintah dan pihak manajemen sendiri (Martono, 2005:52).

Pentingnya pengukuran kinerja perusahaan dapat dijelaskan dengan dua teori yaitu teori keagensi (agency theory)dan teori signal (signalling theory). Pada teori keagensi (agency theory) dijelaskan bahwa pada sebuah perusahaan terdapat dua pihak yang saling berinteraksi. Pihak-pihak tersebut adalah pemilik perusahaan (pemegang saham) dan manajemen perusahaan. Pemegang saham disebut sebagai prinsipal, sedangkan manajemen orang yang diberi kewenangan oleh pemegang saham untuk menjalankan perusahaan yang disebut agen. Teori kedua yang menjelaskan pentingnya pengukuran kinerja adalah teorisignal (signalling theory). Teori signal membahas bagaimana seharusnya signal-signal keberhasilan atau kegagalan manajemen (agen) disampaikan kepada pemilik (principal). Teori signal menjelaskan bahwa pemberian signal dilakukan oleh manajemen untuk mengurangi informasi asimetris.

Rasio CAMEL banyak digunakan untuk menganalisis Kinerja keuangan dari lembaga keuangan terutama bank untuk menentukan kekuatan keuangan mereka secara keseluruhan. Tata cara Penilaian Tingkat Kesehatan bank di atur dalam Surat Edaran Bank Indonesia No. 6/23/DNPN tanggal 31 Mei 2004, yang mengacu pada unsur-unsur CAMEL. Lima kriteria yaitu Modal (Capital), Aktiva (Asset), Manajemen, Pendapatan (Earnings), 
dan Likuiditas (Liquidity) merupakan satu kesatuan dari CAMEL tersebut.

Bank Perkreditan Rakyat atau BPR adalah bank yang menjalankan kegiatan usaha secara konvensional atau berprinsip syariah yang kegiatannya tidak memberikan jasa lalu lintas pembayaran. Bank Perkreditan Rakyat melaksanakan kegiatan usaha seperti penghimpunan dana dalam bentuk tabungan, penyaluran kredit dan deposito berjangka artinya hanya terbatas dengan transaksi yang sederhana. Kegiatan BPR adalah bertujuan untuk melayani usaha kecil dan masyarakat. Tujuan utama BPR adalah memberikan pelayanan kepada usaha mikro kecil dan menengah serta masyarakat sekitar.

Berdasarkan kutipan dari berita online Suara Indonesia.com tanggal 28 Februari 2017 Kepala OJK Regional 4 Jawa Timur, Sukamto menyatakan bahwa Sampai dengan akhir Desember 2016, volume usaha BPR/S milik Pemerintah Jawa Timur mencapai sebesar Rp 5,17 triliun atau tumbuh 8,75\%, Dana Pihak Ketiga (DPK) sebesar Rp3,1 triliun atau tumbuh 13,01\% dan penyaluran Kredit/Pembiayaan sebesar Rp3,86 triliun atau tumbuh $14,45 \%$. Namun kontribusi BPR/S milik Pemda terhadap perekonomian daerah masih tergolong kecil, tercermin dari pangsa kredit/pembiayaan produktif yang disalurkan oleh BPR/S milik Pemda yang hanya sebesar 50,67\% lebih rendah dibandingkan dengan BPR/ S milik Swasta yang mencapai sebesar 77,12\%.

OJK menilai sinergi antara Pemerintah Daerah dengan BPR/S milik Pemda perlu segera direalisasikan untuk memperbaiki Tata Kelola dan meningkatkan Kinerja BPR/S milik Pemda. Perbaikan Tata Kelola dapat mendorong percepatan program pembangunan daerah melalui penyaluran APBD yang tetap sasaran, khususnya melalui program-program yang terkait dengan peningkatan akses keuangan dan pemberdayaan ekonomi masyarakat. Sementara itu, peningkatan kinerja BPR/S milik Pemda dapat berdampak positif terhadap peningkatan deviden sebagai salah satu Pendapatan Asli Daerah (PAD).

NPL atau yang disebut Non Performing Loan mencerminkan risiko kredit, semakin tinggi tingkat NPL maka semakin besar pula risiko kredit yang ditanggung oleh pihak bank (Ali, 2004). Akibat tingginya NPL perbankan harus menyediakan pencadangan yang lebih besar, sehingga pada akhirnya modal bank ikut terkikis. Capital Adequacy Ratio adalah rasio permodalan yang menunjukan kemampuan bank dalam menyediakan dana untuk keperluan pengembangan usaha dan menampung kemungkinan resiko kerugian yang diakibatkan dalam opersional bank (Ahmad dan Kusuno, 2003). Loan to deposit ratio adalah rasio yang mengukur kemampuan kredit yang telah disalurkan guna membayar semua dana masyarakat serta modal sendiri. Semakin tinggi Loan to deposit ratio maka kemampuan kredit yang telah disalurkan oleh bank juga semakin tinggi guna membayar kewajiban jangka pendeknya seperti membayar kembali pencairan dana deposan dari kreditur, bunga yang seharusnya diberikan, dan memenuhi permintaan kredit oleh debitur.

KAP merupakan rasio antara Aktiva Produktif yang diklasifikasikan (APYD) terhadap Total Aktiva Produktif. APYD merupakan aktiva produktif baik yang sudah maupun yang mengandung potensi tidak memberikan penghasilan atau menimbulkan kerugian, sedangkan Total Aktiva Produktif total dari penanaman dana Bank dalam bentuk kredit, surat berharga, penyertaan dan penanaman lainnya yang dimaksudkan untuk memperoleh penghasilan. Sedangkan, BOPO menunjukkan efisiensi bank dalam menjalankan usaha pokoknya (Muljono, 2001). Dalam pengumpulan dana terutama dana masyarakat (dana pihak ketiga), diperlukan biaya selain biaya bunga termasuk biaya iklan. 
Profitabilitas merupakan indikator yang paling penting untuk mengukur kinerja suatu bank. Return On Assets (ROA) memfokuskan kemampuan perusahaan untuk memperoleh Earning dalam kegiatan operasi perusahaan dengan memanfaatkan aktiva yang dimilikinya. Tujuan utama operasional bank adalah mencapai tingkat profitabilitas yang maksimal. ROA penting bagi bank karena

ROA digunakan untuk mengukur efektivitas perusahaan di dalam menghasilkan keuntungan dengan memanfaatkan aktiva yang dimilikinya. Profitabilitas merupakan kemampuan bank untuk menghasilkan/ memperoleh laba secara efektif dan efisien. Profitabilitas yang digunakan adalah ROA karena dapat memperhitungkan kemampuan manajemen bank dalam mengelola aktiva yang dimilikinya untuk menghasilkan income. Semakin besar ROA suatu bank, semakin besar pula tingkat keuntungan yang dicapai bank tersebut dan semakin baik pula posisi bank tersebut dari segi penggunaan asset (Dendawijaya, 2009:118).

Selain itu, dalam penentuan tingkat kesehatan suatu bank, Bank Indonesia lebih mementingkan penilaian Return On Assets (ROA) dari pada Return On Equity (ROE) karena Bank Indonesia lebih mengutamakan nilai profitabilitas suatu bank yang diukur dengan asset yang dananya sebagian besar berasal dari dana simpanan masyarakat sehingga ROA lebih mewakili dalam mengukur tingkat profitabilitas perbankan (Dendawijaya, 2009:119). Oleh karena itu tujuan penelitian ini adalah menganalisis komposisi kinerja keuangan BPR milik swasta dengan BPR milik pemerintah daerah.

\section{LANDASAN TEORI DAN PENGEMBANGAN HIPOTESIS}

\section{Kinerja Keuangan}

Kinerja keuangan adalah penentuan ukuran-ukuran tertentu yang dapat mengukur keberhasilan suatu organisasi atau perusahaan dalam menghasilkan laba (Sucipto, 2003: 34). Sedangkan, menurut (IAI, 2007) Kinerja Keuangan adalah kemampuan perusahaan dalam mengelola dan mengendalikan sumber daya yang dimilikinya.

Dari pengertian diatas dapat ditarik kesimpulan bahwa kinerja keuangan adalah usaha formal yang telah dilakukan oleh perusahaan yang dapat mengukur keberhasilan perusahaan dalam menghasilkan laba, sehingga dapat melihat prospek, pertumbuhan, dan potensi perkembangan baik perusahaan dengan mengandalkan sumber daya yang ada. Suatu perusahaan dapat dikatakan berhasil apabila telah mencapai standar dan tujuan yang telah ditetapkan.

Beberapa penelitian yang telah dilakukan seperti, Hevi Zainuri yang berjudul Analisis komparasi kinerja keuangan Bank Perkreditan Rakyat dan Bank Pembiayaan Rakyat Syariah di Indonesia periode 2014-2015. dengan menggunakan rasio keuangan yakni meliputi Capital Adequacy Ratio (CAR), Return on Assets (ROA), Non Performing Loan (NPL), Loan to Deposit Ratio (LDR), dan Biaya Operasional dan Pendapatan Operasional (BOPO). Hasil penelitiannya menunjukan bahwa terdapat perbedaan yang signifikan untuk masing-masing rasio keuangan Bank Perkreditan Rakyat dan Bank Pembiayaan Rakyat Syariah di Indonesia dengan keseluruhan kinerja Bank Perkreditan Rakyat lebih baik daripada Bank Pembiayaan Rakyat Syariah pada periode penelitian. Dalam penelitian ini terdapat rasio-rasio yang dipergunakan untuk menilai tingkat kesehatan bank yaitu rasio NPL, CAR, LDR, KAP, BOPO dan ROA. 


\section{Non Performing Loan (NPL)}

Kelancaran debitur dalam membayar kewajibannya, yaitu pokok angsuran dan bunga, adalah sebuah keharusan. Karena bank merupakan lembaga intermediasi perbankan yang bertugas menampung dan menyalurkan dana dari dan ke masyarakat. Sehingga pembayaran kredit oleh debitur merupakan sebuah keharusan agar kegiatan operasional bank tetap dapat berjalan dengan lancar. Apabila terjadi banyak penunggakan pembayaran kredit oleh debitur maka berarti bank tidak bisa mendapatkan kembali modal yang telah dikeluarkannya, dan hal itu tentu saja dapat mempengaruhi tingkat kesehatan bank dan bisa berefek pada penurunan tingkat kepercayaan masyarakat. Dampak dari keberadaan NPL dalam jumlah besar tidak hanya berdampak pada bank yang bersangkutan, tetapi juga meluas dalam cakupan nasional apabila tidak dapat ditangani dengan tepat.

\section{$\mathrm{H}_{1}$ : Terdapat perbedaan NPL BPR milik Swasta dan BPR milik Pemerintah Daerah.}

\section{Capital Adequacy Ratio (CAR)}

Permodalan merupakan hal yang pokok bagi sebuah bank, selain sebagai penyangga kegiatan operasional sebuah bank, modal juga sebagai penyangga terhadap kemungkinan terjadinya kerugian. Modal ini terkait juga dengan aktivitas perbankan dalam menjalankan fungsinya sebagai lembaga intermediasi atas dana yang diterima nasabah. Dengan terjaganya modal berarti bank bisa mendapatkan kepercayaan dari masyarakat yang amat penting artinya bagi sebuah bank karena dengan demikian, bank dapat menghimpun dana untuk keperluan operasional selanjutnya (Sinungan, 2000).

\section{$\mathrm{H}_{2}$ : Terdapat perbedaan CARBPR milik Swasta dan BPR milik Pemerintah Daerah.}

\section{Loan to Deposit Ratio (LDR)}

Loan to deposit ratio adalah rasio yang mengukur kemampuan kredit yang telah disalurkan guna membayar semua dana masyarakat serta modal sendiri. Semakin tinggi Loan to deposit ratio maka kemampuan kredit yang telah disalurkan oleh bank juga semakin tinggi guna membayar kewajiban jangka pendeknya seperti membayar kembali pencairan dana deposan dari kreditur, bunga yang seharusnya diberikan, dan memenuhi permintaan kredit oleh debitur. Menurut anjuran Bank Indonesia, LDR yang aman adalah pada kisaran 78\% sampai 100\%. Apabila suatu bank mampunyai tingkat LDR lebih dari 100\%, maka harus menambah GWM sebesar 0,2\% untuk setiap peningkatan LDR sebesar 1\%. Untuk memenuhi anjuran Bank Indonesia tersebut, maka bank berusaha untuk menaikkan rasio LDR selama rasio

\section{$\mathrm{H}_{3}$ : Terdapat perbedaan LDR BPR milik Swasta dan BPR milik Pemerintah Daerah.}

\section{Kualitas Aktiva Produktif (KAP)}

KAP merupakan rasio antara Aktiva Produktif yang diklasifikasikan (APYD) terhadap Total Aktiva Produktif. APYD merupakan aktiva produktif baik yang sudah maupun yang mengandung potensi tidak memberikan penghasilan atau menimbulkan kerugian, sedangkan Total Aktiva Produktif total dari penanaman dana Bank dalam bentuk kredit, surat berharga, penyertaan dan penanaman lainnya yang dimaksudkan untuk 
memperoleh penghasilan.

\section{$\mathrm{H}_{4}$ : Terdapat perbedaan KAP BPR milik Swasta dan BPR milik Pemerintah Daerah.}

\section{Beban Operasional dan PendapatanOperasional (BOPO)}

Pengendalian biaya terhadap pendapatan operasional dapat diukur melalui rasio BOPO. BOPO adalah perbandingan antara Biaya Operasional terhadap Pendapatan Operasional. Biaya Operasional adalah semua jenis biaya yang dikeluarkan oleh Bank/ BPR/ Perusahaan untuk mendapatkan penghasilan, misalnya: Beban Bunga, Beban Pemasaran, Beban Tenaga Kerja dan Beban Operasional. Lainnya. Sementara Pendapatan Operasional adalah pendapatan yang diperoleh dari Penempatan Dana Antar Bank, Penyaluran Dana dalam bentuk kredit dan pendapatan operasional lainnya sehubungan dengan kegiatan perusahaan. Semakin kecil rasio yang terbentuk maka semakin efisiens biaya operasional yang dikeluarkan oleh perusahaan bersangkutan. Dalam lingkup BPR, rasio ini dikatakan sehat apabila rasio $<=93,52 \%$.

\section{$\mathrm{H}_{5}$ : Terdapat perbedaan BOPO BPR milik Swasta dan BPR milik Pemerintah Daerah.}

\section{Return on Asset (ROA)}

Return on Assets (ROA) merupakan salah satu rasio profitabilitas. Dalam analisis laporan keuangan, rasio ini paling sering disoroti, karena mampu menunjukkan keberhasilan perusahaan menghasilkan keuntungan. ROA mampu mengukur kemampuan perusahaan manghasilkan keuntungan pada masa lampau untuk kemudian diproyeksikan di masa yang akan datang. Assets atau aktiva yang dimaksud adalah keseluruhan harta perusahaan, yang diperoleh dari modal sendiri maupun dari modal asing yang telah diubah perusahaan menjadi aktivaaktiva perusahaan yang digunakan untuk kelangsungan hidup perusahaan.

\section{$\mathrm{H}_{6}$ : Terdapat perbedaan ROA BPR milik Swasta dan BPR milik Pemerintah Daerah.}

\section{METODE PENELITIAN}

\section{Jenis dan Sumber Data}

Penelitian ini menggunakan data sekunder berupa laporan keuangan Tahunan baik BPR Milik Swasta maupun Milik Pemerintah daerah se Provinsi Jawa Tengah tahun 2014-2016. Sumber data berasal dari laporan publikasi OJK, website resmi OJK yaitu http://www.ojk.go.id. Penelitian ini dilaksanakan selama 4 bulan dari bulan maret 2018 sampai dengan Juni 2018.

\section{Definisi Operasional dan Pengukuran Variabel}

\section{Non Performing Loan (NPL)}

Non Performing Loan (NPL) menunjukkan kemampuan manajemen bank dalam mengelola kredit bermasalah yang diberikan oleh bank (Herdaningtyas, 2002). NPL mencerminkan risiko kredit, semakin tinggi tingkat NPL maka semakin besar pula risiko kredit yang ditanggung oleh pihak bank (Ali, 2004).

Bank Indonesia menetapkan nilai NPL maksimum adalah sebesar 5\%, apabila bank melebihi batas yang diberikan maka bank tersebut dikatakan tidak sehat. Menurut Surat Edaran Bank Indonesia No. 6/23/DPNP 
tanggal 31 Mei 2004 dapat dihitung dengan cara sebagai berikut:

$$
\begin{gathered}
\text { Total Kredit Bermasalah } \\
\text { TPL }=\text { Total Kredit }
\end{gathered}
$$

\section{Capital Adequacy Ratio (CAR)}

Capital Adequacy Ratio adalah rasio permodalan yang menunjukan kemampuan bank dalam menyediakan dana untuk keperluan pengembangan usaha dan menampung kemungkinan resiko kerugian yang diakibatkan dalam opersional bank (Ahmad dan Kusuno, 2003).

Menurut Peraturan dari Bank Indonesia No. 10/15/PBI/2008 menyatakan bahwa bank wajib menyediakan modal minimum sebesar $8 \%$ dari aset tertimbang menurut risiko(ATMR). Menurut Surat Edaran Bank Indonesia No. 6/23/DPNP tanggal 31 Mei 2004 dapat dihitung dengan rumus sebagai berikut:

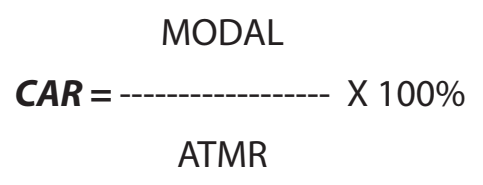

\section{Loan to Deposit Ratio (LDR)}

Dendawijaya (2009) menyatakan bahwa Loan to Deposit Ratio (LDR) menunjukkan seberapa jauh kemampuan bank dalam membayar kembali penarikan dana yang dilakukan deposan dengan mengandalkan kredit yang diberikan sebagai sumber likuiditasnya. Menurut Hamonangan dan Siregar dalam Galih (2011) mengatakan bahwa LDR digunakan untuk mengukur seberapa jauh kemampuan bank guna membayar semua dana masyarakat serta modal sendiri dengan mengandalkan kredit yang telah didistribusikan ke masyarakat.

Pengukuran rasio LDR menurut Surat Edaran Bank Indonesia No.6/23/DPNP tanggal 31 Mei 2004 dapat dihitung dengan rumus sebagai berikut:

$$
\text { LDR = } \frac{\text { Total Kredit Bermasalah }}{\text { Dana Pihak Ketiga }}
$$

\section{Kualitas Aktiva Produktif (KAP)}

KAP merupakan rasio antara aktiva produktif yang diklasifikasikan (APYD) terhadapTotal aktiva produktif. APYD merupakan aktiva produktif baik yang sudah maupun yang mengandung potensi tidak memberikan penghasilan atau menimbulkan kerugian, sedangkan Total Aktiva Produktif total dari penanaman dana Bank dalam bentuk kredit, suratberharga, penyertaan dan penanaman lainnya yang dimaksudkan untuk memperoleh penghasilan (Muljono, 2001). Menurut Surat Edaran Bank Indonesia No. 6 / 23 / DPNP tanggal 31 
Mei 2004 dapat dihitung dengan rumus sebagai berikut:

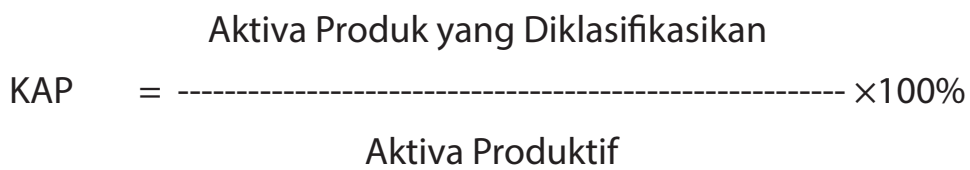

Beban Operasional dan Pendapatan Operasional (BOPO)

BOPO menunjukkan efisiensi bank dalam menjalankan usaha pokoknya (Muljono, 2001). Dalam pengumpulan dana terutama dana masyarakat (dana pihak ketiga), diperlukan biaya selain biaya bunga (termasuk biaya iklan). Menurut Surat Edaran Bank Indonesia No. 6/ 23/ DPNP tanggal 31 Mei 2004 dapat dihitung dengan rumus sebagai berikut:

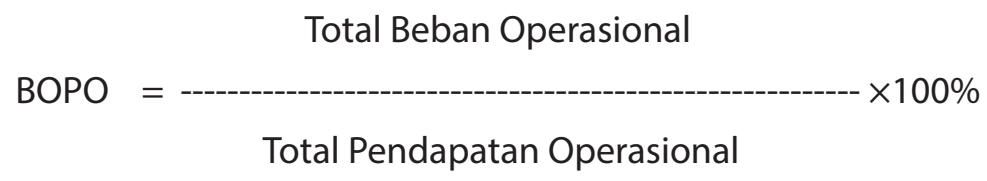

\section{Return on Assets (ROA)}

Dendawijaya (2009) mengemukakan bahwa Return On Asset (ROA) digunakan untuk mengukur kemampuan manajemen bank dalam memperoleh laba secara keseluruhan dari total aktiva yang dimiliki. Menurut Surat Edaran Bank Indonesia No. 6/23/DPNP tanggal 31 Mei 2004 dapat dihitung dengan rumus sebagai berikut:

$$
\text { ROA = } \begin{gathered}
\text { Laba Sebelum Pajak } \\
\text { Rata------------------------ x 100\% }
\end{gathered}
$$

\section{Populasi dan Sampel Penelitian}

Populasi yang digunakan dalam penelitian ini adalah BPR yang berada di Provinsi Jawa Tengah. Sampel penelitian ini adalah BPR Milik Swasta maupun Milik Pemerintah Daerah (Pemprov, Pemkab, Pemkot) yang memiliki asset tertinggi 10 besar di Jawa Tengah. Pemilihan sampel dengan menggunakan purposive sampling. Dengan kriteria sebagai berikut:

a. BPR yang melaporkan laporan keuangannya di website OJK.

b. BPR Milik Swasta dan Milik Pemerintah Daerah yang berada di Provinsi Jawa Tengah.

C. Periode Laporan Tahun 2014 - 2016

d. Laporan keuangannya berisi tentang variabel-variabel yang diteliti.

e. Yang memiliki Ranking asset 10 besar, BPR Milik Swasta dan Milik Pemerintah Daerah yang berada di Provinsi Jawa Tengah pada saat periode Laporan. 


\section{Metode Analisis Data}

Pada penelitan ini menggunakan Alat analisis Independent Sample T-test (Uji Beda), karena menggunakan 2 kelompok yang tidak berpasangan, artinya sumber data berasal dari subjek yang berbeda yaitu kinerja Bank Perkreditan Rakyat milik Pemerintah daerah dan milik swasta dengan aplikasi program SPSS 19.

\section{HASIL PENELITIAN DAN PEMBAHASAN}

\section{Statistik Deskriptif}

Untuk memberikan gambaran dan informasi mengenai data variabel dalam penelitian ini maka digunakan tabel statistik deskiptif.Dalam penelitian ini ditemukan 5 buah data outlier, sehingga membuat sampel penelitian yang sebelumnya berjumlah 30 sampel untuk BPR milik pemerintah daerah menjadi 29 sampel, sedangkan untuk BPR milik swasta sebelumnya berjumlah 30 sampel menjadi 26 sampel.Hasil dari pengujian statistik deskriptif dapat dilihat pada tabel 1.

a. Analisis Deskriptif Ratio NPL Rata-rata keseluruhan rasio NPL pada BPR milik PEMDA yaitu sebesar 4,1003\%, sedangkan rasio NPL pada BPR milik Swasta sebesar 2,7765\%. Berdasarkan nilai rata-rata NPL menunjukan bahwa secara statistik selama periode penelitian NPL BPR di Jawa Tengah telah memenuhi standar yang ditetapkan oleh Bank Indonesia yaitu sebesar 5\%, Tetapi kinerja BPR dalam mengelola kredit bermasalah masih lebih baik BPR milik swasta dibandingkan BPR milik PEMDA.

b. Analisis Deskriptif Ratio CAR Rata-rata keseluruhan rasio CAR pada BPR milik PEMDA yaitu sebesar $18,7121 \%$, sedangkan rasio CAR pada BPR milik Swasta sebesar 17,4392\%. Berdasarkan nilai rata-rata CAR menunjukan bahwa secara statistik selama periode penelitian besarnya CAR BPR di Jawa Tengah yang dijadikan sampel sudah memenuhi standar yang ditetapkan oleh Bank Indonesia, yaitu minimum 12\%. Sehingga dapat disimpulkan rasio kecukupan modal yang dimiliki BPR di Jawa Tengah dapat dikatakan cukup tinggi.Tetapi aspek kecukupan modal BPR milik PEMDA masih cukup tinggi dibandingkan BPR milik Swasta.

c. Analisis Deskriptif Ratio LDR Rata-rata keseluruhan rasio LDR pada BPR milik PEMDA yaitu sebesar 79,4962\%, sedangkan rasio LDR pada BPR milik Swasta sebesar 82,5992\%. Berdasarkan nilai rata-rata LDR menunjukan bahwa secara statistik selama periode penelitian LDR BPR di Jawa Tengah memenuhi standar yang ditetapkan oleh Bank Indonesia yaitu berkisar 80\% - 110\%.Tetapi kinerja rasio LDR BPR milik PEMDA masih lebih baik dibandingkan BPR milik swasta.

d. Analisis Deskriptif Ratio KAP Rata-rata keseluruhan rasio KAP pada BPR milik PEMDA yaitu sebesar 4,3803\%, sedangkan rasio KAP pada BPR milik Swasta sebesar 2,7165\%.Berdasarkan nilai rata-rata KAP menunjukan bahwa secara statistik selama periode penelitian KAP BPR di Jawa Tengah memenuhi standar yang ditetapkan oleh Bank Indonesia yaitu dibawah 10,35\%.Tetapi kinerja rasio KAP BPR milik Swasta masih lebih baik dibandingkan BPR milik PEMDA.

e. Analisis Deskriptif Rasio BOPO Rata-rata keseluruhan rasio BOPO pada BPR milik PEMDA yaitu sebesar $76,5276 \%$, sedangkan rasio BOPO pada BPR milik Swasta sebesar 77,3358\%. Berdasarkan nilai rata-rata 
BOPO menunjukan bahwa secara statistik selama periode penelitian BOPO BPR di Jawa Tengah memenuhi standar yang ditetapkan oleh Bank Indonesia yaitu dibawah 93,52\%. Tetapi kinerja rasio BOPO BPR milik PEMDA masih lebih baik dibandingkan BPR milik Swasta.

f. Analisis Deskriptif Rasio ROA Rata-rata keseluruhan rasio ROA pada BPR milik PEMDA yaitu sebesar 3,7769\%, sedangkan rasio ROA pada BPR milik Swasta sebesar 3,9446\% Berdasarkan nilai rata-rata ROA menunjukan bahwa secara statistik selama periode penelitian ROA BPR di Jawa Tengah memenuhi standar yang ditetapkan oleh Bank Indonesia yaitu diatas 1,215\%.Tetapi kinerja rasio ROA BPR milik Swasta masih lebih baik dibandingkan BPR milik PEMDA.

Banyak teknik pengujian normalitas suatu distribusi data yang telah dikembangkan oleh para ahli. Beberapa teknik yang bisa kita gunakan untuk menguji normalitas data adalah melalui rumus KolmogorovSmirnov, ShapiroWilk dan secara deskriptif melalui grafik Q-Q Plot, Box Plot, Histogram, Kurtosis dan Skewness. Dalam Penelitian ini menggunakan teknik Kolmogorov-Sminov dalam menguji normalitas data. Untuk alat analisis menggunakan SPSS Versi 19. Hasil uji Normalitas data dapat dilihat pada tabel 2.

Berdasarkan hasil olah data Uji Normalitas Kolmogorov Smirnov menunjukan nilai Asymp. Sig.(2tailed) adalah 0,640, nilai tersebut di atas 0,05 maka dapat disimpulkan bahwa tidak terdapat perbedaan yang signifikan antara data yang diuji dengan data normal baku. Artinya data yang diuji memiliki distribusi normal.

\section{Pengujian Independent Sample T test}

Alat analisis yang digunakan adalah Independent Sample T-test (Uji Beda) dengan program SPSS 19. Tabel 4 menyajikan data hasil dari pengujian Independen Sampel T test.

\section{Analisis Ratio NPL (Non Performing Loan).}

Berdasarkan tabel diatas hasil uji Independent Sample T-test (Uji Beda)rasio keuangan NPL di BPR milik PEMDA dan BPR milik Swasta memiliki F hitung sebesar 1,357 dengan signifikansi 0,249, karena signifikansinya $>0,05$ maka Ho diterima, sehingga rasio keuangan NPL antara BPR milik PEMDA dan BPR milik Swasta memiliki varians yang sama, sedangkan bila kedua varians sama, maka dalam uji t akan lebih tepat menggunakan dasar equal variances assumed yang dimana bahwa t statistik NPL adalah 2,286 dengan signifikasi 0,026<0,05 maka Ho ditolak atau dapat disimpulkan rasio keuangan NPL antara BPR milik PEMDA dan BPR milik Swasta terdapat perbedaan yang signifikan.

Standar terbaik dari Bank Indonesia untuk rasio NPL adalah kurang dari 5\%. Rata-rata keseluruhan NPL pada BPR milik PEMDA dan BPR milik Swasta masing-masing memiliki hasil rata-rata kurang dari 5\%, yaitu BPR milik PEMDA yaitu sebesar 4,1003\%, sedangkan rasio NPL pada BPR milik Swasta sebesar 2,7765\%. Ini menunjukan bahwa BPR swasta masih lebih baik dalam mengelola kredit bermasalah dibandingkan BPR milik PEMDA. Hal ini dikarenakan BPR milik Swasta lebih mempertimbangkan pada profit oriented sehingga BPR milik Swasta sangat ketat dalam memantau kredit yang bermasalahnya, semakin banyak kredit yang bermasalah akan mengakibatkan bank akan membentuk biaya PPAP (Penyisian penghapuasan Aset Produktif) 
akan semakin besar pula, yang mengakibatkan penurunan laba perusahaan.

\section{Analisis Ratio CAR (Capital Adequacy Ratio)}

Berdasarkan tabel diatas hasil uji Independent Sample T-test (Uji Beda) rasio keuangan CAR di BPR milik PEMDA dan BPR milik Swasta memiliki F hitung sebesar 0.343 dengan signifikansi 0,561.karena signifikansinya $>0,05$ maka Ho diterima, sehingga rasio keuangan CAR antara BPR milik PEMDA dan BPR milik Swasta memiliki varians yang sama, sedangkan bila kedua varians sama, maka dalam uji t akan lebih tepat menggunakan dasar equal variances assumed yang dimana bahwa t statistik CAR adalah 0,888 dengan signifikasi 0,379>0,05 maka Ho diterima atau dapat disimpulkan rasio keuangan CAR antaraBPR milik PEMDA dan BPR milik Swasta tidak terdapat perbedaan. Hal ini dikarenakan Pihak Otoritas Jasa Keuangan sangat ketat untuk memantau BPR dalam segi permodalan, baik BPR milik Swasta maupun milik PEMDA sesuai dengan POJK No.5/POJK.03/2015 mengenai Kewajiban Penyediaan Modal Minimum dan pemenuhan Modal Inti Minimum, Apabila tidak memenuhi dalam segi permodalan BPR diminta untuk menambah Modal BPR ataupun dengan melakukan Merger maupun Akuisisi dengan BPR lain.

\section{Analisis Ratio LDR (Loan to Deposit Ratio)}

Berdasarkan tabel diatas hasil uji Independent Sample T-test (Uji Beda) rasio keuangan LDR di BPR milik PEMDA dan BPR milik Swasta memiliki $F$ hitung sebesar 0.487 dengan signifikansi 0,488. Karena signifikansinya $>0,05$ maka Ho diterima, sehingga rasio keuangan LDR antara BPR milik PEMDA dan BPR milik Swasta memiliki varians yang sama, sedangkan bila kedua varians sama, maka dalam uji t akan lebih tepat menggunakan dasar equal variances assumed yang dimana bahwa t statistik LDR adalah -1,536 dengan signifikasi 0,131>0,05 maka Ho diterima atau dapat disimpulkan rasio keuangan LDR antara BPR milik PEMDA dan BPR milik Swasta tidak terdapat perbedaan.

Rata-rata keseluruhan rasio LDR pada BPR milik PEMDA yaitu sebesar 79,4962\%, sedangkan rasio LDR pada BPR milik Swasta sebesar 82,5992\%. Berdasarkan nilai rata-rata LDR menunjukan bahwa secara statistik selama periode penelitian LDR BPR di Jawa Tengah memenuhi standar yang ditetapkan oleh Bank Indonesia yaitu berkisar $80 \%$ - 110\%. Hal ini menunjukan tidak ada perbedaan yang signifikan terhadap ratsio LDR, artinya baik BPR PEMDA maupun Swasta sangat berhati-hati dalam menyalurkan kredit dari dana yang dihimpun untuk mempertahankan likuditas Bank agar bank dapat berjalan dengan lancar.

\section{Analisis Ratio KAP (Kualitas Aktiva Produktif)}

Berdasarkan tabel diatas hasil uji Independent Sample T-test (Uji Beda) rasio keuangan KAP di BPR milik PEMDA dan BPR milik Swasta memiliki $F$ hitung sebesar 1,786 dengan signifikansi 0,187, karena signifikansinya $>0,05$ maka Ho diterima, sehingga rasio keuangan KAP antara BPR milik PEMDA dan BPR milik Swasta memiliki varians yang sama, sedangkan bila kedua varians sama, maka dalam uji t akan lebih tepat menggunakan dasar equal variances assumed yang dimana bahwa t statistik KAP adalah 3,582 dengan signifikasi 0,001<0,05 maka Ho ditolak atau dapat disimpulkan rasio keuangan KAP antara BPR milik PEMDA dan BPR milik Swasta terdapat 
perbedaan yang signifikan.

Standar terbaik dari Bank Indonesia untuk rasio KAP adalah kurang dari 10,35\%. Rata-rata keseluruhan KAP pada BPR milik PEMDA dan BPR milik Swasta masing-masing memiliki hasil rata-rata kurang dari 10,35\%, yaitu BPR milik PEMDA yaitu sebesar 4,3803\%, sedangkan rasio KAP pada BPR milik Swasta sebesar 2,7165\%. Ini menunjukan bahwa BPR swasta masih lebih baik dalam mengelola kredit bermasalah dibandingkan BPR milik PEMDA Hal ini berbanding lurus dengan rasio NPL yang dimiliki BPR, semakin baik rasio NPL yang dimiliki BPR maka semakin baik pula dengan Kualitas Aset Produktif yang dimilikinya, dalam kasus penelitian ini rasio KAP BPR milik Swasta masih lebih baik di bandingkan BPR milik Pemerintah Daerah.

\section{Analisis Ratio BOPO (Beban Operasional dan Pendapatan Operasional)}

Berdasarkan tabel diatas hasil uji Independent Sample T-test (Uji Beda) rasio keuangan BOPO di BPR milik PEMDA dan BPR milik Swasta memiliki $F$ hitung sebesar 10,050 dengan signifikansi 0,003 . Karena signifikansinya $<0,05$ maka Ho ditolak, sehingga rasio keuangan BOPO antara BPR milik PEMDA dan BPR milik Swasta memiliki varians yang berbeda, sedangkan bila kedua varians berbeda, maka dalam uji t akan lebih tepat menggunakan dasar equal variancesnot assumed yang dimana bahwa t statistik BOPO adalah -0,501 dengan signifikasi 0,619> 0,05 maka Ho diterima atau dapat disimpulkan rasio keuangan BOPO antara BPR milik PEMDA dan BPR milik Swasta tidak terdapat perbedaan.

Berdasarkan Rata-rata keseluruhan rasio BOPO pada BPR milik PEMDA yaitu sebesar 76,5276\%, sedangkan rasio BOPO pada BPR milik Swasta sebesar 77,3358\%.Berdasarkan nilai rata-rata BOPO menunjukan bahwa secara statistik selama periode penelitian BOPO BPR di Jawa Tengah memenuhi standar yang ditetapkan oleh Bank Indonesia yaitu dibawah 93,52\%. Hal ini menunjukan tidak ada perbedaan yang signifikan rasio BOPO BPR Swasta maupun PEMDA, artinya kedua kepemilikan BPR tersebut masih memperhitungkan efesiensi agar dapat memaksimalkan laba yang diperoleh.

\section{Analisis Ratio ROA (Return on Asset)}

Berdasarkan tabel diatas hasil uji Independent Sample T-test (Uji Beda) rasio keuangan ROA di BPR milik PEMDA dan BPR milik Swasta memiliki F hitung sebesar 22,034 dengan signifikansi 0,000. Karena signifikansinya $<0,05$ maka Ho ditolak, sehingga rasio keuangan ROA antara BPR milik PEMDA dan BPR milik Swasta memiliki varians yang berbeda, sedangkan bila kedua varians berbeda, maka dalam uji t akan lebih tepat menggunakan dasar equal variance snot assumed yang dimana bahwa t statistik ROA adalah -0,569 dengan signifikasi 0,573> 0,05 maka Ho diterima atau dapat disimpulkan rasio keuangan ROA antara BPR milik PEMDA dan BPR milik Swasta tidak terdapat perbedaan.

Berdassarkan rata-rata keseluruhan rasio ROA pada BPR milik PEMDA yaitu sebesar 3,7769\%, sedangkan rasio ROA pada BPR milik Swasta sebesar 3,9446\%. Hal ini menunjukan tidak ada perbedaan yang signifikan rasio ROA BPR Swasta maupun PEMDA, ini artinya kedua kepemilikan BPR tersebut dapat memaksimalkan asset yang di dapat untuk memperoleh laba. Bank Indonesia lebih mengutamakan nilai profitabilitas suatu bank yang diukur dengan asset yang dananya sebagian besarberasal dari dana simpanan masyarakat sehingga ROA 
lebih mewakili dalam mengukur tingkat profitabilitas perbankan Berdasarkan nilai rata-rata ROA menunjukan bahwa secara statistik selama periode penelitian ROA BPR di Jawa Tengah memenuhi standar yang ditetapkan oleh Bank Indonesia yaitu diatas 1,215\%.

\section{KESIMPULAN, KETERBTASAN DAN SARAN}

\section{Kesimpulan}

Berdasarkan Pengujian Hipotesis yang telah dilakukan menggunakan Uji Independet T testdengan aplikasi program SPSS Ver 19, kesimpulan hipotesis adalah:

1. Terdapat perbedaan rasio keuangan NPL antara BPR milik PEMDA dan BPR milik Swasta yang signifikan. BPR swasta masih lebih baik dalam mengelola kredit bermasalah dibandingkan BPR milik PEMDA

2. Tidak Terdapat perbedaan rasio keuangan CAR antara BPR milik PEMDA dan BPR milik Swasta. Tetapi aspek rata-rata kecukupan modal BPR milik PEMDA masih cukup tinggi dibandingkan BPR milik Swasta.

3. Tidak Terdapat perbedaan rasio keuangan LDR antaraBPR milik PEMDA dan BPR milik Swasta. Tetapi rata-rata kinerja rasio LDR BPR milik PEMDA masih lebih baik dibandingkan BPR milik swasta.

4. Terdapat perbedaan rasio keuangan KAP antara BPR milik PEMDA dan BPR milik Swasta. Tetapi rataratakinerja rasio KAP BPR milik Swasta masih lebih baik dibandingkan BPR milik PEMDA.

5. Tidak terdapat perbedaan rasio keuangan BOPO antara BPR milik PEMDA dan BPR milik Swasta yang signifikan.Tetapi rata-rata kinerja rasio BOPO BPR milik PEMDA masih lebih baik dibandingkan BPR milik Swasta

6. Tidak terdapat perbedaan rasio keuangan ROA antara BPR milik PEMDA dan BPR milik Swasta yang signifikan. Tetapi rata-rata kinerja rasio ROA BPR milik Swasta masih lebih baik dibandingkan BPR milik PEMDA.

\section{Implikasi Manajerial}

Dari hasil kesimpulan diatas maka peneliti memberikan saransebagai berikut:

a. Bagi BPR milik PEMDA

BPR milik Pemerintah Daerah di Jawa Tengah unggul dalam permodalan dilihat dari rasio CAR, dalam efesiensi dapat dilihat dari rasio BOPO, serta rasio penyaluran kredit dibandingkan dengan dana yang dihimpun dapat dilihat dari rasio LDR, tetapi dalam aspek mengelola kredit bermasalah dapat dilihat dari rasio NPL dan KAP masih tidak lebih unggul dari pada BPR milik Swasta. Maka BPR milik PEMDA perlu melakukan langkah-langkah sebagai berikut,

1. Melakukan maintenance kredit bermasalah secara berkesinambungan, dengan melakukan restrukturisasi kredit ataupun melakukan penagihan kredit yang bermasalah secara intensif.

2. Melakukan Analisa Kredit dengan prinsip kehati-hatian sebelum kredit dapat terealisasi. Dengan melakukan langkahlangkah preventif tersebut diharapkan dapat memaksimalkan labanya dengan memanfaatkan asset yang 
dipunyai (rasio ROA)

b. Bagi BPR milik Swasta BPR milik Swasta di Jawa tengah unggul dalam aspek mengelola kredit bermasalah dapat dilihat dari rasio NPL dan KAP, serta dapat memaksimalkan labanya dengan memanfaatkan asset yang dipunyai dapat dilihat dari rasio ROA, tetapi dalam aspek permodalan dilihat dari rasio CAR, dalam efesiensi dapat dilihat dari rasio BOPO, serta rasio penyaluran kredit dibandingkan dengan dana yang dihimpun dapat dilihat dari rasio LDR masih tidak lebih unggul dari pada BPR milik PEMDA. Maka BPR milik Swasta perlu melakukan langkah-langkah sebagai berikut,

1. Memperkuat dalam segi Permodalan sesuai yang diatur oleh POJK No.5/POJK.03/2015 mengenai "Kewajiban Penyediaan Modal Minimum dan pemenuhan Modal Inti Minimum", Apabila tidak memenuhi dalam segi permodalan BPR diminta untuk menambah Modal BPR dengan batasan waktu yang telah ditentukan ataupun dengan melakukan Merger maupun Akuisisi dengan BPR lain.

2. Menjaga likuditas Bank dengan menerapkan prinsip kehatihatian (Prudential Banking) dalam menyalurkan kredit dari dana yang dihimpun dari masyarakat agar operasional bank dapat berjalan dengan lancar.

\section{Agenda Penelitian Mendatang}

Dapat diujikan kembali dengan menambahkan Variabel-Variabel lain dari penelitian yang terdahulu seperti pada penelitian mengenai Jasa di Obyek yang berbeda.

Sampel yang digunakan hanya sebatas Bank Perkreditan Rakyat Se Provinsi Jawa Tengah. Untuk penelitian mendatang dapat dikembangkan Sampel yang lebih luas. 


\section{DAFTAR PUSTAKA}

Ariefianto, Moch Doddy. 2012. Ekonometrika. Jakarta: PT Gelora Aksara Pratama.

Bank Indonesia. 1998. Undang-Undang Republik 2002. Peraturan Bank Indonesia
Indonesia No.10/1998 tentang perbankan.

No. $\quad 4 / 10 / P B I / 2002$.

Jakarta.

2004. Surat Edaran Bank Indonesia No. 6/23/DNPN tanggal 31 Mei 2004. Jakarta.

Dendawijaya, Lukman. 2009. Manajemen Perbankan. Edisi Kedua. Jakarta: Ghalia Indonesia.

Ghozali, Imam. 2013.Aplikasi Analisis Multivariate ～dengan Program SPSS. Edisi Ketujuh Semarang: Badan

Penerbit Universitas Diponegoro.

Hasan, Iqbal. 2010. Analisis Data Penelitian Dengan Statistik. Jakarta: PT Bumi Aksara.

Hasibuan, Malayu S.P. 2006. Dasar-dasar Perbankan. Jakarta: Bumi Aksara.

Kasmir, 2013. Bank \& Lembaga Keuangan Lainnya. Jakarta: PT. Raja Grafindo Persada.

Manurung, Mandala dan Rahardja, Pratama. 2004. Uang, Perbankan, dan Ekonomi Moneter

(Kajian Kontekstual Indonesia). Jakarta: FE UI.

Marzuki. 2005. Metodologi Riset. Yogyakarta: Pustaka Pelajar.

Muljono, Teguh Pudjo. 2001. Manajemen Perkreditan Rakyat Bagi Bank Komersil. $\quad$ Yogyakarta: Badan Pendidikan Fakultas Ekonomi UGM.

Peraturan Mendgri. 2006. Pengelolaan Bank Perkreditan Rakyat milik Pemerintah Daerah.No.22 tanggal 23 Juni 2006.

Putri, Pramesti Dwi dan I Wyn Pradnyantha Wirasedana. 2015. Analisis Perbandingan Penilaian kinerja BPR dengan Pendekatan Balanced Scorecard. E-Jurnal Akuntansi Universitas Udayana, 13.1 (2015): 1-19.

Siamat, Dahlan. 2004. Manajemen Lembaga Keuangan-Kebijakan Moneter dan Perbankan. Jakarta: Fakultas Ekonomi Universitas Indonesia.

Sinungan, Muchdarsyah. $\quad$ 2000. Manajemen Dana Bank. Jakarta: PT Bumi Aksara

Sugiyono. 2008. Metodologi Penelitian Bisnis (Pendekatan Kuantitatif, Kualitatif, dan R\&D). Bandung: Alfabeta.

Sukirno, Sadono. 2004. Pengantar Teori Makro Ekonomi. Edisi Ketiga. Jakarta: Raja Grafindo Persada.

Suliyanto dan Dian Purnomo Jati. 2014. Perbandingan Efesiensi Bank Perkreditan Rakyat dan Bank

Umum dengan Pendekatan data Envelopment Analisis. Jurnal Keuangan dan Perbankan Vol 12. No,2 hal 297-306

Taswan. 2006. Manajemen Perbankan. Yogyakarta : UPP STIM YKPN.

Universitas Semarang. 2016. Pedoman Penyusunan Pelitian Dosen. Fakultas Ekonomi. S e m a r a n g: Universitas Semarang.

Widiastiti, Kadek Yenni dan I Ketut Yadnyana. 2013. Analisis perbandingan kinerja PT.BPR Mitra Balijaya Mandiri dan PT.BPR Cahaya Bina Werdhi dengan Pendekatan Balanced Scorecard. EJurnal Akuntansi Universitas Udayana, 4.3 (2013): 605-621.

Zainuri, Hevi. 2015. Analisis komparasi kinerja keuangan Bank Perkreditan Rakyat dan Bank Pembiayaan Rakyat Syariah di Indonesia periode 2014-2015. Jurnal FEB Universitas Muhamadiyah.Yogyakarta.

www. Suara Indonesia. com

70

Jurnal Akuntansi Indonesia

Vol. 8 No. 1 Januari 2019 


\section{LAMPIRAN}

Tabel 1 Uji Statistik Deskriptif

\begin{tabular}{|c|c|c|c|c|c|}
\hline \multicolumn{6}{|c|}{ Group Statistics } \\
\hline & BPR & $\mathrm{N}$ & Mean & Std. Deviation & $\begin{array}{r}\text { Std. Error } \\
\text { Mean }\end{array}$ \\
\hline \multirow[t]{2}{*}{ NPL } & $\begin{array}{l}\text { Bpr } \\
\text { pemda }\end{array}$ & 29 & 4.1003 & 2.32203 & .43119 \\
\hline & Bpr swasta & 26 & 2.7765 & 1.92469 & .37746 \\
\hline \multirow[t]{2}{*}{ CAR } & $\begin{array}{l}\text { Bpr } \\
\text { pemda }\end{array}$ & 29 & 18.7121 & 5.00679 & .92974 \\
\hline & Bpr swasta & 26 & 17.4392 & 5.62545 & 1.10324 \\
\hline \multirow[t]{2}{*}{ LDR } & $\begin{array}{l}\text { Bpr } \\
\text { pemda }\end{array}$ & 29 & 79.4962 & 6.75920 & 1.25515 \\
\hline & Bpr swasta & 26 & 82.5992 & 8.21556 & 1.61120 \\
\hline \multirow[t]{2}{*}{ KAP } & $\begin{array}{l}\text { Bpr } \\
\text { pemda }\end{array}$ & 29 & 4.3803 & 1.98029 & .36773 \\
\hline & Bpr swasta & 26 & 2.7165 & 1.37101 & .26888 \\
\hline \multirow[t]{2}{*}{ BOPO } & $\begin{array}{l}\text { Bpr } \\
\text { pemda }\end{array}$ & 29 & 76.5276 & 4.27701 & .79422 \\
\hline & Bpr swasta & 26 & 77.3358 & 7.16235 & 1.40465 \\
\hline \multirow[t]{2}{*}{ ROA } & $\begin{array}{l}\text { Bpr } \\
\text { pemda }\end{array}$ & 29 & 3.7769 & .66039 & .12263 \\
\hline & Bpr swasta & 26 & 3.9446 & 1.36639 & .26797 \\
\hline
\end{tabular}

Sumber : Data yang diolah

Tabel 2

Uji Normalitas BPR milik Pemerintah Daerah

\begin{tabular}{|c|c|c|c|c|c|c|c|}
\hline & & NPL & CAR & LDR & KAP & BOPO & ROA \\
\hline \multicolumn{2}{|l|}{$N$} & 29 & 29 & 29 & 29 & 29 & 29 \\
\hline \multirow{2}{*}{\multicolumn{2}{|c|}{$\begin{array}{l}\text { Nor Mean } \\
\text { mal } \\
\text { Par Std. mtr Dev }\end{array}$}} & 4.10 & 18.71 & 79.4 & 4.38 & \multirow{2}{*}{$\begin{array}{r}76.52 \\
4.27\end{array}$} & 3.77 \\
\hline & & 2.32 & 5.006 & 6.75 & 1.98 & & .660 \\
\hline \multirow{3}{*}{$\begin{array}{l}\text { Mos } \\
\text { t } \\
\text { Extr } \\
\text { eme } \\
\text { Diff }\end{array}$} & Abs & .146 & .202 & .147 & .169 & .135 & .131 \\
\hline & Post & .146 & .202 & .082 & .107 & .135 & .131 \\
\hline & Negt & .131 & -.117 & .147 & .169 & -.060 & -.122 \\
\hline \multirow{2}{*}{\multicolumn{2}{|c|}{$\begin{array}{l}\text { KolmogorovSmirnov Z } \\
\text { Asymp. Sig. } \\
\text { (2-tailed) }\end{array}$}} & .788 & 1.088 & .793 & .911 & .728 & .705 \\
\hline & & .563 & .187 & .555 & .377 & .665 & .703 \\
\hline
\end{tabular}

Sumber : Data yang diolah 
Tabel 3

Uji Normalitas BPR milik Swasta

\begin{tabular}{|c|c|c|c|c|c|c|c|}
\hline & & NPL & CAR & LDR & KAP & BOPO & ROA \\
\hline \multicolumn{2}{|l|}{$\mathrm{N}$} & 26 & 26 & 26 & 26 & 26 & 26 \\
\hline \multirow{2}{*}{$\begin{array}{l}\text { Nor } \\
\text { mal } \\
\text { Par } \\
\text { mtr }\end{array}$} & \multirow[b]{2}{*}{1.924} & $\begin{array}{l}17.4 \\
392\end{array}$ & $\begin{array}{c}82.59 \\
92\end{array}$ & $\begin{array}{r}2.71 \\
65\end{array}$ & $\begin{array}{l}77.3 \\
358\end{array}$ & 3.9446 & 3.77 \\
\hline & & $\begin{array}{l}5.62 \\
545\end{array}$ & $\begin{array}{c}8.215 \\
56\end{array}$ & $\begin{array}{l}1.37 \\
101\end{array}$ & $\begin{array}{l}7.16 \\
235\end{array}$ & 1.3663 & .660 \\
\hline Mos & .166 & .256 & .099 & .100 & .124 & .127 & .131 \\
\hline \multicolumn{2}{|c|}{$\mathrm{t}$} & .256 & .078 & .099 & .124 & .102 & .131 \\
\hline \multicolumn{2}{|c|}{ Diff } & .166 & -.099 & .100 & .091 & -.127 & -.122 \\
\hline $\begin{array}{l}\text { Kolm } \\
\text { Asym } \\
\text { (2-tai }\end{array}$ & $\begin{array}{l}\text { orovSmirnov Z } \\
\text { Sig. }\end{array}$ & .847 & 1.307 & .505 & .512 & .632 & 649 \\
\hline
\end{tabular}

Sumber : Data yang diolah

Tabel 4

Uji Independet Samples Test

\begin{tabular}{|c|c|c|c|c|c|c|}
\hline & & \multicolumn{2}{|c|}{$\begin{array}{l}\text { Levene's Test } \\
\text { for Equality } \\
\text { of Variances }\end{array}$} & \multicolumn{3}{|c|}{$\begin{array}{l}\text { t-test for Equality of } \\
\text { Means }\end{array}$} \\
\hline & & $\mathrm{F}$ & Sig. & $\mathrm{t}$ & Df & $\begin{array}{c}\text { Sig. } \\
\text { (2tailed) }\end{array}$ \\
\hline \multirow[t]{2}{*}{ NPL } & Equal variances assum & 1.357 & .249 & 2.286 & 53 & .026 \\
\hline & $\begin{array}{l}\text { Equal variances } \\
\text { not assum }\end{array}$ & & & 2.310 & 52.697 & .025 \\
\hline \multirow[t]{2}{*}{ CAR } & Equal variances assum & .343 & .561 & .888 & 53 & .379 \\
\hline & $\begin{array}{l}\text { Equal variances } \\
\text { not assum }\end{array}$ & & & .882 & 50.415 & .382 \\
\hline \multirow[t]{2}{*}{ LDR } & Equal variances assum & .487 & .488 & -1.536 & 53 & .131 \\
\hline & $\begin{array}{l}\text { Equal variances } \\
\text { not assum }\end{array}$ & & & -1.519 & 48.577 & .135 \\
\hline \multirow[t]{2}{*}{ KAP } & Equal variances assum & 1.786 & .187 & 3.582 & 53 & .001 \\
\hline & $\begin{array}{l}\text { Equal variances } \\
\text { not assum }\end{array}$ & & & 3.652 & 49.951 & .001 \\
\hline
\end{tabular}


JURNAL AKUNTANSI INDONESIA

\begin{tabular}{|c|c|c|c|c|c|c|}
\hline \multirow[t]{2}{*}{ BOPO } & Equal variances assum & $\begin{array}{l}10.0 \\
50\end{array}$ & .003 & -.514 & 53 & .609 \\
\hline & $\begin{array}{c}\text { Equal variances } \\
\text { not assum }\end{array}$ & & & -.501 & 39.899 & .619 \\
\hline \multirow[t]{2}{*}{ ROA } & $\begin{array}{c}\text { Equal variances } \\
\text { assumed }\end{array}$ & $\begin{array}{r}22.0 \\
34\end{array}$ & .000 & -.589 & 53 & .558 \\
\hline & $\begin{array}{c}\text { Equal variances } \\
\text { not assumed }\end{array}$ & & & -.569 & 35.190 & .573 \\
\hline
\end{tabular}

Sumber : Data yang diolah 